\title{
Composition and distribution of NSO compounds in two different shales at the early maturity stage characterized by negative ion electrospray ionization coupled with Fourier transform ion cyclotron resonance mass spectrometry
}

\author{
Chang-Wei Ke $\mathrm{K}^{1,2} \cdot$ Yao-Hui Xu $\mathrm{X}^{1,2} \cdot$ Xiang-Chun Chang $^{3} \cdot$ Wei-Bin Liu $^{4}$
}

Received: 26 July 2017 / Published online: 3 May 2018

(c) The Author(s) 2018

\begin{abstract}
Gas chromatography/mass spectrometry (GC/MS) can only analyze volatile molecular compounds, and it has limitations when applied to determine the complex components of crude oils and hydrocarbon source rocks. Based on Fourier transform ion cyclotron resonance mass spectrometry (FT-ICR-MS) and GC/MS analyses, the molecular compositions of NSO compounds in extracts from the Permian Dalong Formation, Sichuan Basin and the Permian Lucaogou Formation, Junggar Basin in China were compared. Analyses of types of heteroatoms present $\left(\mathrm{S}_{1}, \mathrm{~S}_{2}, \mathrm{~S}_{3}, \mathrm{OS}, \mathrm{OS}_{2}, \mathrm{O}_{2} \mathrm{~S}, \mathrm{NS}\right.$, and NOS compounds) suggest that marine shales from the Dalong Formation are mainly composed of carboxylic acids $\left(\mathrm{O}_{2}\right.$ compounds) with a high abundance of fatty acids, indicating a marine phytoplankton organic source. However, lacustrine shales from the Lucaogou Formation are dominated by pyrrolic compounds $\left(\mathrm{N}_{1}\right.$ compounds) with abundant dibenzocarbazole. It suggests that the organic source materials may be derived from lower aquatic organisms and lacustrine algae. Overall, FT-ICR-MS has potential for applications in analyses and determination of depositional environments and organic sources in petroleum geology.
\end{abstract}

Keywords Fourier transform ion cyclotron resonance mass spectrometry · Dalong Formation · Lucaogou Formation . NSO compounds $\cdot$ Sedimentary environment

Edited by Jie Hao

Yao-Hui Xu

Yaohuixu@126.com

1 Key Laboratory of Exploration Technologies for Oil and Gas Resources (Yangtze University), Ministry of Education, Wuhan 430100, Hubei, China

2 College of Resources and Environment, Yangtze University, Wuhan 430100, Hubei, China

3 College of Earth Science and Engineering, Shandong University of Science and Technology, No. 579 Qianwangang Road, Huangdao District, Qingdao 266590, Shandong, China

4 Oil and Gas Survey, China Geological Survey, Beijing 100029, China

\section{Introduction}

Crude oils are composed of complex hydrocarbons and nonhydrocarbons. Traditionally, column chromatography is used to separate the aliphatic hydrocarbons, aromatics, resins, and asphaltenes. Aliphatic and aromatic hydrocarbons are then analyzed by gas chromatography (GC), GCMS, and GC along with coupled tandem mass spectrometry. However, for nonhydrocarbons and bitumen with strong polarity and high molecular weights, it is difficult to analyze them systematically and comprehensively using these traditional methods. Although nitrogen, sulfur and oxygen (NSO) compounds are not predominant in crude oils, their distribution and composition greatly affect the characteristic of crude oils. For example, the amount of sulfur directly determines the quality of crude oils. Considering that the distribution and characteristics of NSO compounds are related to the source material, depositional environment and other factors thus the analysis of NSO 
compounds can help determine the formation, generation and evolution of petroleum (Wang 2002; Wang et al. 2004; Li et al. 2001).

Currently, Fourier transform ion cyclotron resonance mass spectrometry (FT-ICR-MS) is widely used to determine the differences of polar compounds in crude oils from different districts with various maturity and biodegradation degrees (Qian et al. 2001; Hughey et al. 2004, 2007). But the geological background of the source rock and biomarkers were not taken into consideration in many studies. Certain standards and indexes have not been proposed yet (Kim et al. 2005; Stanford et al. 2007). In addition, limited research concerning the differences among the NSO compounds from lacustrine shales and marine shales has been reported. This research is to investigate the NSO compounds of shale extracts from the Dalong Formation in the Sichuan Basin (Fu et al. 2010; Liang et al. 2009; Xia et al. 2010) and the Lucaogou Formation in the Junggar Basin, China (Zhao et al. 1994; Peng et al. 2011) using negative ion electrospray ionization (ESI) coupled with FT-ICR-MS, and compare their differences and similarities from analyses of the composition of the acidic and neutral nitrogen heteroatom compounds.

\section{Samples and experimental methods}

\subsection{Samples}

Marine shale from the Dalong Formation (Kushan Liang Section) in the Sichuan Basin is characterized by relatively high total organic carbon $(\mathrm{TOC}=10.60 \%)$, type $\mathrm{II}_{1}$ organic matter, and low maturity $\left(R_{\mathrm{O}}=0.74 \%\right)$. However, the total organic carbon of lacustrine shale from the Dalong Formation (Dalongkou Section) in the southern part of the Junggar Basin is relatively lower than that of marine shale with a value of $7.82 \%$. Lacustrine shale is in an early thermal stage $\left(R_{\mathrm{O}}=0.78 \%\right)$ with type I organic matter (Table 1).

\subsection{The method of GC-MS}

Using the mass spectrometer $(6890 \mathrm{~N} \mathrm{GC/5975} \mathrm{MSD}$ developed by the company of Agilent), the chloroform bitumen "A" was analyzed by gas chromatography mass spectrometry after Soxhlet extraction and rotational evaporation. The chromatographic conditions are $30 \mathrm{~m} \times 0.25 \mathrm{~mm} \times 0.25 \mu \mathrm{m}$, with conventional chromatographic column type of HP-5MS. The operating temperature for the pulse-splitless inlet was $300{ }^{\circ} \mathrm{C}$ using constant current mode, in which the flow rate was $1.0 \mathrm{~mL} /$ min, the temperature program was at $50,20^{\circ} \mathrm{C} / \mathrm{min}$ to $100{ }^{\circ} \mathrm{C}, 3{ }^{\circ} \mathrm{C} / \mathrm{min}$ to $310^{\circ} \mathrm{C}$ and the constant temperature should be held for $21 \mathrm{~min}$. MS conditions: using electron impact (EI) ionization mode, with an ionization energy of $70 \mathrm{eV}$, a filament current of $34.6 \mathrm{~mA}$ scan mode full scan (50-550 Da) ion scanning, the temperature of ions is $230{ }^{\circ} \mathrm{C}$ and the temperature of the four stage pole is $150{ }^{\circ} \mathrm{C}$.

\subsection{The experiments and analysis for ESI FT-ICR- MS}

Bitumen "A" was extracted by Soxhlet extraction and rotary evaporation. Then, we dissolved $10 \mathrm{mg}$ bitumen "A" in $1 \mathrm{~mL}$ of toluene, diluted with toluene/methanol (1:3) to give a final content of $0.2 \mathrm{mg} / \mathrm{mL}$, and added $1 \mu \mathrm{L}$ of ammonia (Lu et al. 2013; Shi et al. 2010). Finally, the solution was shaken gently to stimulate the acidic compounds and neutral nitrogen to generate the ion $[\mathrm{M}-\mathrm{H}]^{-}$.

The samples were analyzed using a Bruker Apex-ultra FT-ICR-MS equipped with a Bruker 9.4 T actively shielded superconducting magnet. The sample solution was infused via an Apollo IV electrospray source at $180 \mu \mathrm{L} / \mathrm{h}$ using a syringe pump. The operating conditions for negative ion formation were $-3.5 \mathrm{kV}$ emitter voltage, $-4.0 \mathrm{kV}$ capillary column front end voltage, and $-4.0 \mathrm{kV}$ capillary column end voltage. Ions were accumulated for $0.01 \mathrm{~s}$ in a hexapole. The quadrupole (Q1) was optimized to obtain a broad range for ion transfers. An argon-filled hexapole collision cell was operated at $5 \mathrm{MHz}$ and $400 \mathrm{Vp}-\mathrm{p}$ RF amplitude, in which ions accumulated for $0.02 \mathrm{~s}$. The extraction period for ions from the hexapole to the ICR cell was set to $1.2 \mathrm{~ms}$. The excitation was attenuated at $12 \mathrm{~dB}$ and was used to excite ions over the range of 110-800 Da. 128 scans were used to enhance the signalto-noise ratio and the dynamic range.

We used software from the China University of Petroleum (Beijing) to calculate the combination of various molecular compounds $\mathrm{C}, \mathrm{H}, \mathrm{O}, \mathrm{N}$ and $\mathrm{S}$ atoms, and the

Table 1 Basic geochemical data for TOC, vitrinite reflectance, and Rock-Eval results of the Dalong and Lucaogou Formations

\begin{tabular}{llllllllll}
\hline Sample & Formation & Bitumen “A”, $\%$ & TOC, $\%$ & $\mathrm{~S} 1+\mathrm{S} 2, \mathrm{mg} / \mathrm{g}$ & $\mathrm{HI}, \%$ & $T_{\max },{ }^{\circ} \mathrm{C}$ & $R_{\mathrm{o}}, \%$ & $\mathrm{Pr} / \mathrm{Ph}$ & $\mathrm{Type}$ \\
\hline 1 & Dalong & 0.51 & 10.6 & 29.91 & 305 & 442 & 0.74 & 0.89 & $\mathrm{II}_{1}$ \\
2 & Lucaogou & 0.41 & 7.82 & 41.18 & 502 & 448 & 0.78 & 1.13 & $\mathrm{I}$ \\
\hline
\end{tabular}


molecular mass peak corresponding to the type (the subscript of $\mathrm{C}_{c} \mathrm{H}_{h} \mathrm{O}_{o} \mathrm{~N}_{n} \mathrm{~S}_{s}$ represented the number of different atoms). All types of molecular compounds in the sample would be given with DBE (Double Band Equivalence) which is equal to the number of molecular structure of naphthenic rings added with the number of double bands. The formula for calculating DBE is DBE $=c-h / 2+n /$ $2+1$ (Kendrick 1963; Liu et al. 2010; Shi et al. 2013).

\section{Results and discussion}

\subsection{The results of GC-MS}

The Dalong Formation shale has a large content of $n$ alkanes with the highest content of $n \mathrm{C}_{15}$. The pristine/phytane ratio is 0.89 , while the abundance of gammacerane is relatively low (Fig. 1) with a ratio of 0.06 for the index of gammacerane (gammaceranes/ $\mathrm{C}_{30}$ $\alpha \beta$ hopanes), indicating a reducing environment. Ts and $\mathrm{C}_{29}$ Ts are also in low abundance, but the concentrations of $\mathrm{Tm}$ and $\mathrm{C}_{29}$ hopanes are fairly high. The $\mathrm{Ts} /(\mathrm{Ts}+\mathrm{Tm})$ and $\mathrm{C}_{29} \mathrm{Ts} / \mathrm{C}_{29}$ hopanes ratios are 0.17 and 0.09 , respectively. In addition, as the number of carbon atoms increases, the abundance of $\mathrm{C}_{31}{ }^{+}$hopanes increase, too. The abundances of pregnanes and homopregnanes are relative high, while the (pregnanes + homopregnanes)/total regular steranes ratio is 0.18 . The relative abundances of the $\mathrm{C}_{28}$ and $\mathrm{C}_{29}$ steranes are higher than the $\mathrm{C}_{27}$ steranes (the relative abundances of $\mathrm{C}_{28}$ steranes are $17.1 \%, \mathrm{C}_{27}$ steranes are $33.1 \%$, and $\mathrm{C}_{29}$ steranes are $49.9 \%$ ), so the compositional fingerprint of $\mathrm{C}_{27}-\mathrm{C}_{28}-\mathrm{C}_{29}$ steranes is $\mathrm{V}$-shaped
(Fig. 1). The index of maturity $20 \mathrm{~S} /\left(\mathrm{C}_{29} 20 \mathrm{~S}+\mathrm{C}_{29} 20 \mathrm{R}\right)$ of $\mathrm{C}_{29}$ steranes is 0.53 with the index of $\mathrm{C}_{29} \beta \beta /\left(\mathrm{C}_{29}\right.$ $\left.\beta \beta+C_{29} \alpha \alpha\right)$ is 0.45 . And $C_{31}$ sublimation hopanes $22 \mathrm{~S} /$ $(22 \mathrm{~S}+22 \mathrm{R})$ is 0.60 . These values indicate the shales from the Dalong Formation are mature (Luo et al., 2016).

The shale extracts from the Permian Lucaogou Formation have a severe loss of $n$-alkanes, while the abundances of pristine and phytane are higher than the $\mathrm{C}_{17}$ and $\mathrm{C}_{18}$ alkanes. This indicates the Lucaogou Formation suffered slight biodegradation in the early history of deposition or in the diagenesis stage (Bao 1996). The total ion chromatogram (TIC) shows that a relatively higher abundance of pentacyclic triterpenoids, while the main peak is $\mathrm{C}_{30}$ hopanes. As the number of carbon atoms increases, the abundance of $\mathrm{C}_{31}{ }^{+}$hopanes decline. The pristine/phytane ratio is 1.02 , and the abundance of $\beta$-carotanes is high too. But the gammaceranes have a moderate abundance (Fig. 1) with a ratio of 0.14 , indicating a reducing depositional environment. The abundances of $\mathrm{Ts}$ and $\mathrm{C}_{29} \mathrm{Ts}$ are relative low, but $\mathrm{Tm}$ and $\mathrm{C}_{29}$ hopanes are higher, which is similar to the Dalong Formation. The ratio of $\mathrm{Ts} /(\mathrm{Ts}+\mathrm{Tm})$ is 0.12 , while the $\mathrm{C}_{29} \mathrm{Ts} / \mathrm{C}_{29}$ hopanes is 0.08 . The abundance of pregnanes and homopregnanes is also high, with the (pregnanes + homopregnanes)/total regular steranes ratio is 0.19 . The relative abundances of $\mathrm{C}_{27}$ steranes are lower than the amount of $\mathrm{C}_{28}$ and $\mathrm{C}_{29}$ steranes (the relative abundance of $\mathrm{C}_{27}$ sterane are $17.0 \%$, the $\mathrm{C}_{28}$ sterane are $36.1 \%$, and the $\mathrm{C}_{29}$ steranes are $46.9 \%$ ), so the compositional fingerprint of $\mathrm{C}_{27}-\mathrm{C}_{28}-\mathrm{C}_{29}$ steranes is line-shaped (Fig. 1). The index of maturity $20 \mathrm{~S} /\left(\mathrm{C}_{29} 20 \mathrm{~S}+\mathrm{C}_{29} 20 \mathrm{R}\right)$ of $\mathrm{C}_{29}$ steranes is 0.48 , and $\mathrm{C}_{29} \beta \beta /\left(\mathrm{C}_{29} \beta \beta+\mathrm{C}_{29} \alpha \alpha\right)$ is 0.52 . And $\mathrm{C}_{31}$ homopregnanes $22 \mathrm{~S} /(22 \mathrm{~S}+22 \mathrm{R})$ ratio is 0.48 ,

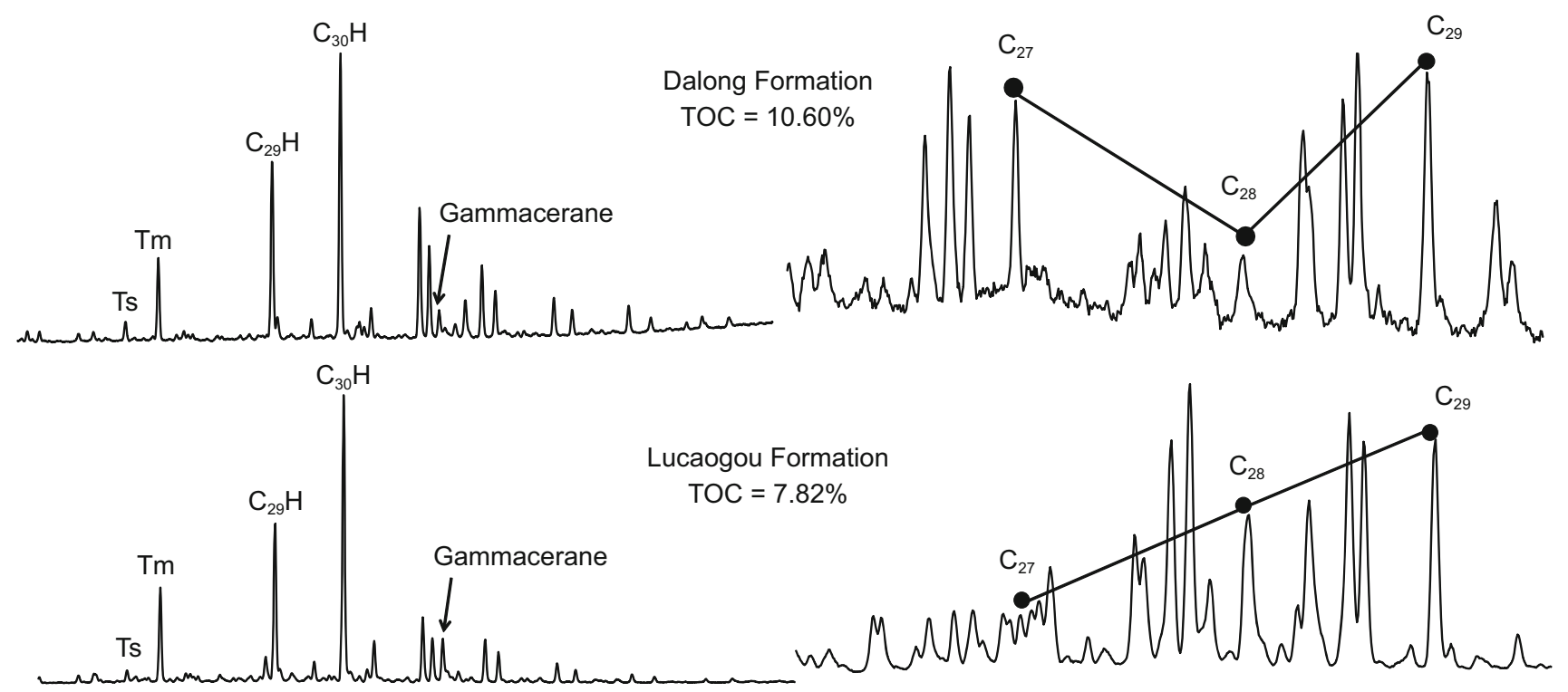

Fig. 1 Mass chromatogram segments $(\mathrm{m} / \mathrm{z}=191$ and $\mathrm{m} / \mathrm{z}=217)$ for the pentacyclic triterpenoids (left) and steranes (right) of the Dalong Formation and the Lucaogou Formation 
indicates the Lucaogou Formation is also mature (Luo et al. 2016, 2017).

The above analyses show that the abundance of organic material is high both in the Dalong and Lucaogou Formations. The types of organic material are $\mathrm{II}_{1}$ and $\mathrm{I}$, and both of them are at the early stage of maturity, indicating the two formations are very good source rocks. However, as for the biomarkers, there are several differences: the Dalong Formation has low abundances of gammacerane, pristine/phytane ratio, $\mathrm{C}_{28}$ steranes, and absent of $\beta$-carotane; while the Lucaogou Formation has higher abundances of these four biomarkers.

\subsection{Distribution of heteroatoms in the extraction of two different source rocks}

The broadband negative ion ESI FT-ICR mass spectrograms show the distributions of different molecular types from the Dalong and Lucaogou Formations. Figure 2 shows that the abscissa is $\mathrm{m} / \mathrm{z}$ with continuous mass spectra peaks It also shows the CG (center of mass) is around $\mathrm{m} /$ $z=400$. The abscissa also represents the distribution of the acidic compounds because the negative ion ESI only ionizes the $[\mathrm{M}-\mathrm{H}]^{-}$. Figure 2 indicates that the characteristics of the two mass spectrograms are different. The mass spectrogram of the extraction from the Dalong Formation is ordinary, and there are a series of mass spectra peaks with adjacent mass number of 14 that distribute continuously to an odd predominance. The mass spectrogram of the Lucaogou Formations is more complex.

Taking the $m / z=382.10-382.40$ fragment of the spectrogram shown in Fig. 3 as an example, 7-8 mass spectrum peaks at the $\Delta(m / z)=0.3$ can be detected. The NSO compounds of the two samples have significant differences, while the molecular composition of these NSO compounds can be confirmed through their accurate molecular weights (Table 2). There is little deviation from the theoretical molecular weight because of the high resolution. The measured molecular weights and the NSO compounds also have obvious differences between the extracts from marine shale and lacustrine shale. Characterizing the acidic compounds and neutral nitrogen compounds by negative ESI FT-ICR MS works well, it indicates that their diversity can be analyzed.

Figure 4 shows the distributions of different compounds classes for the two shales, which includes the types and the quantities of the NSO compounds. The marine shale of the Dalong Formation has many types of NSO compounds, such as $\mathrm{N}_{1}, \mathrm{~N}_{1} \mathrm{O}_{1}, \mathrm{~N}_{1} \mathrm{O}_{2}, \mathrm{~N}_{1} \mathrm{O}_{3}, \mathrm{~N}_{1} \mathrm{O}_{4}, \mathrm{~N}_{1} \mathrm{O}_{1} \mathrm{~S}_{1}, \mathrm{O}_{1}, \mathrm{O}_{2}$, and $\mathrm{O}_{3}$. The $\mathrm{O}_{2}$ compounds have the highest abundance, while

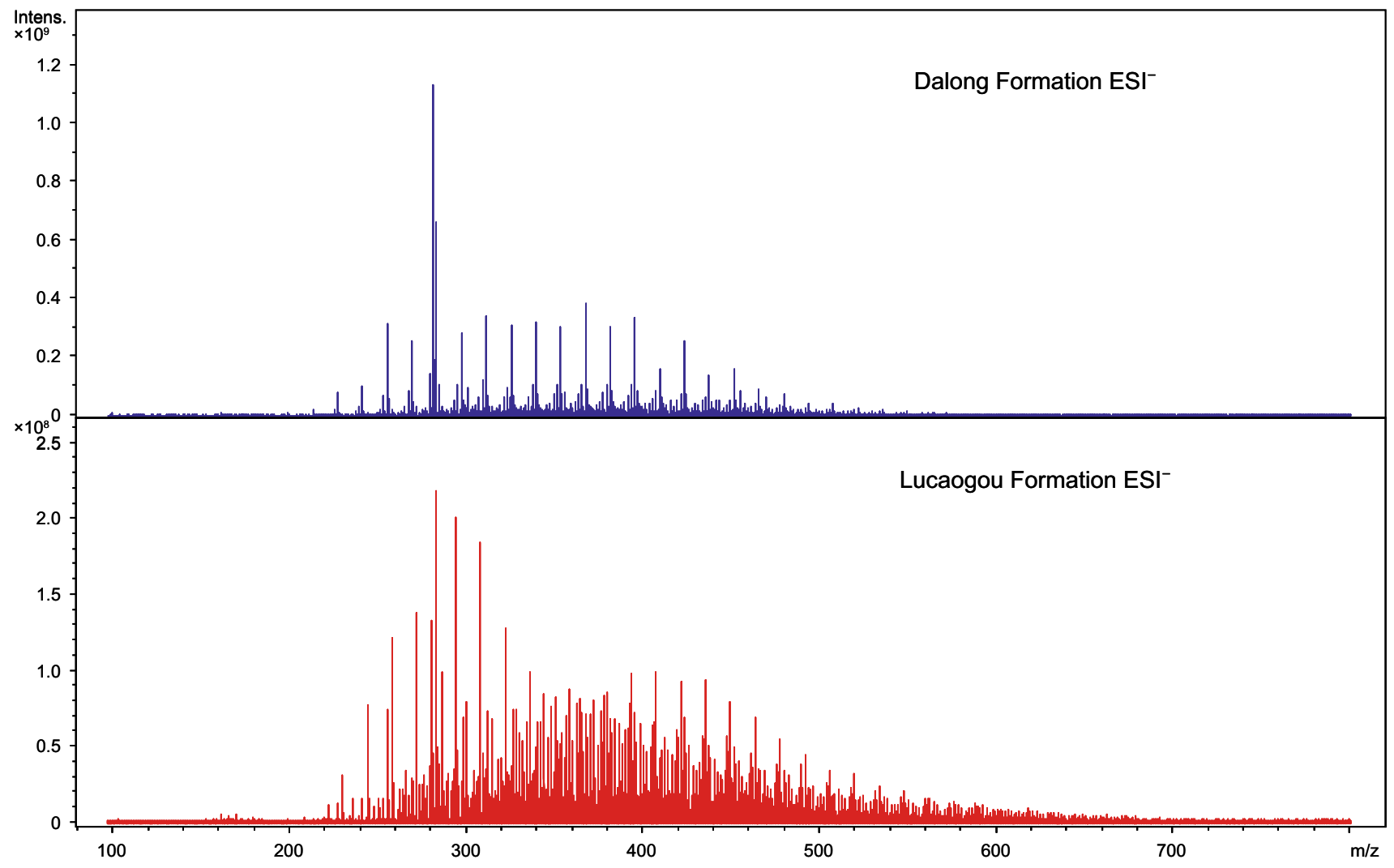

Fig. 2 Broadband negative ion ESI FT-ICR mass spectra of the two asphalts from different sources 

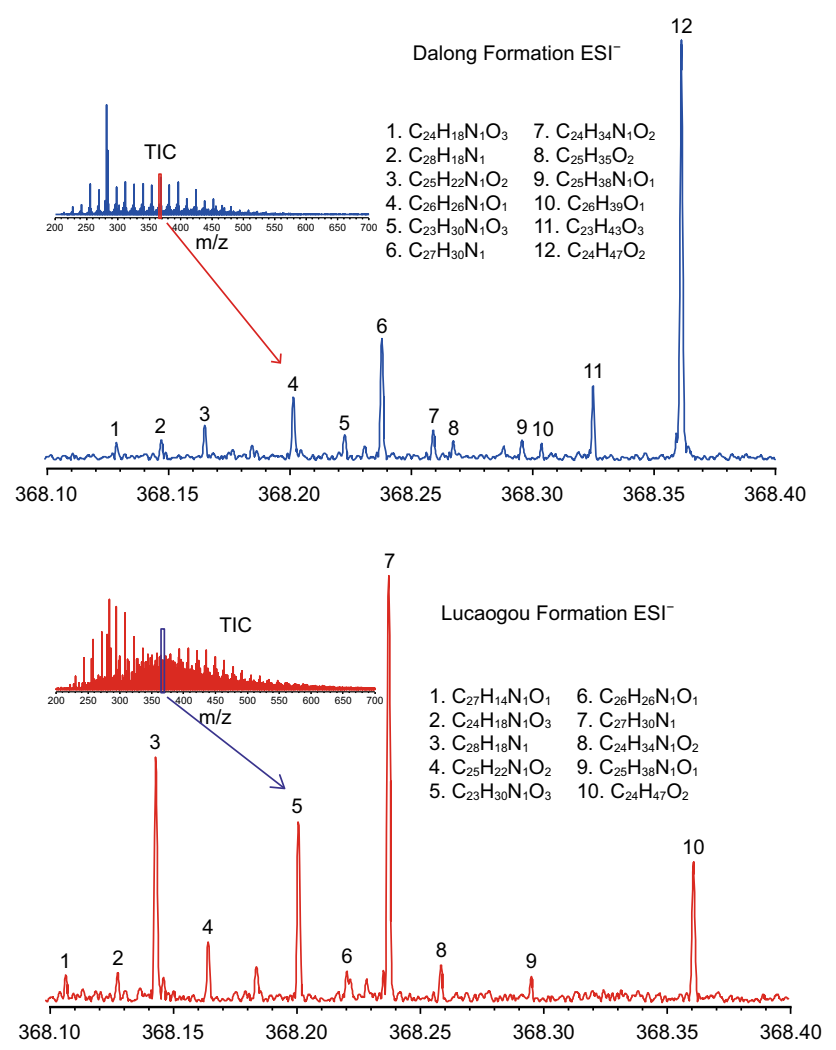

Fig. 3 Expanded negative ion ESI FT-ICR mass spectra of the two asphalts from different sources

the contents of $\mathrm{O}_{3}$ compounds and $\mathrm{N}_{1}$ compounds are lower than $\mathrm{O}_{2}$ compounds, with the lowest proportions of the $\mathrm{N}_{1} \mathrm{O}_{4}$ compounds and $\mathrm{N}_{1} \mathrm{O}_{1} \mathrm{~S}_{1}$ compounds. Compared

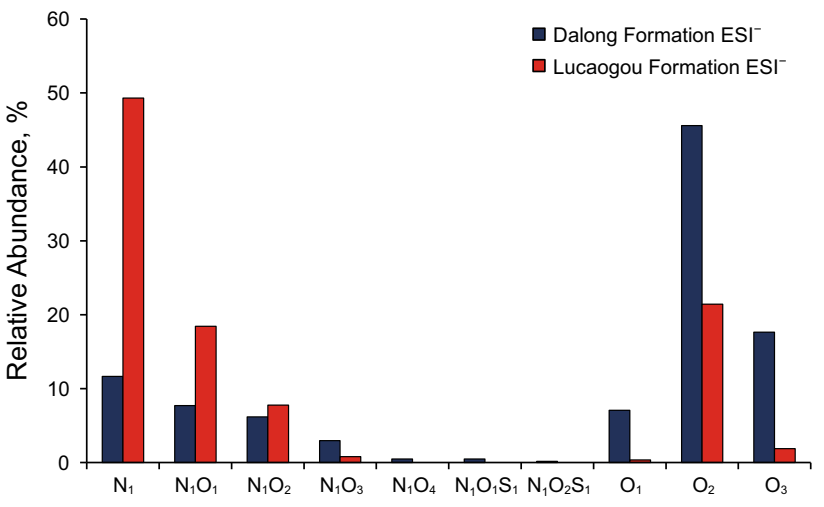

Fig. 4 Relative abundance of heteroatom classes assigned from the negative ion ESI FT-ICR mass spectra of the two asphalts

with the Lucaogou Formation, it also has many types of molecules such as $\mathrm{N}_{1}, \mathrm{~N}_{1} \mathrm{O}_{1}, \mathrm{~N}_{1} \mathrm{O}_{2}, \mathrm{~N}_{1} \mathrm{O}_{3}, \mathrm{O}_{1}, \mathrm{O}_{2}$, and $\mathrm{O}_{3}$. The $\mathrm{N}_{1}$ compounds have the most abundance, while the contents of $\mathrm{N}_{1} \mathrm{O}_{1}$ compounds and $\mathrm{O}_{2}$ compounds are lower than $\mathrm{N}_{1}$ compounds. The $\mathrm{N}_{1} \mathrm{O}_{3}$ compounds, $\mathrm{O}_{1}$ compounds, and $\mathrm{O}_{3}$ compounds have the lowest proportions. The shale of the Lucaogou Formation is lacking of $\mathrm{N}_{1} \mathrm{O}_{4}$ compounds and $\mathrm{N}_{1} \mathrm{O}_{1} \mathrm{~S}_{1}$ compounds.

\subsection{Comparison of the shales}

The analysis of the negative ion ESI FT-ICR MS demonstrates the marine and lacustrine source rocks have the same elemental compositions. The NSO compounds of the marine shale in Sichuan Basin and the lacustrine shale in Junggar Basin have obvious differences. For example, the

Table 2 Data for the broadband negative ion ESI FT-ICR mass spectra between $m / z=382.10-382.40$ of the two asphalts from different sources

\begin{tabular}{|c|c|c|c|c|c|c|}
\hline Formation & Serial number & Molecular formula & Theoretical value & Measured value & Abundance & ppm \\
\hline \multirow[t]{8}{*}{ Dalong Formation } & 1 & $\mathrm{C}_{25} \mathrm{H}_{20} \mathrm{NO}_{3}$ & 382.14 & 382.15 & $5,159,845$ & 0.40 \\
\hline & 2 & $\mathrm{C}_{26} \mathrm{H}_{24} \mathrm{NO}_{2}$ & 382.18 & 382.18 & $10,906,558$ & 0.44 \\
\hline & 3 & $\mathrm{C}_{23} \mathrm{H}_{28} \mathrm{NO}_{2} \mathrm{~S}_{1}$ & 382.18 & 382.18 & $2,651,072$ & 0.12 \\
\hline & 4 & $\mathrm{C}_{27} \mathrm{H}_{28} \mathrm{NO}$ & 382.22 & 382.22 & $16,096,214$ & 0.43 \\
\hline & 5 & $\mathrm{C}_{24} \mathrm{H}_{32} \mathrm{NO}_{3}$ & 382.24 & 382.24 & $3,854,309$ & 0.24 \\
\hline & 6 & $\mathrm{C}_{28} \mathrm{H}_{20} \mathrm{~N}$ & 382.25 & 382.25 & $31,706,095$ & 0.39 \\
\hline & 7 & $\mathrm{C}_{25} \mathrm{H}_{36} \mathrm{NO}_{2}$ & 382.28 & 382.28 & $6,255,613$ & 0.15 \\
\hline & 8 & $\mathrm{C}_{26} \mathrm{H}_{40} \mathrm{NO}$ & 382.31 & 382.31 & $3,687,445$ & 0.53 \\
\hline \multirow[t]{8}{*}{ Lucaogou Formation } & 1 & $\mathrm{C}_{28} \mathrm{H}_{16} \mathrm{NO}$ & 382.12 & 382.12 & $11,853,644$ & 0.30 \\
\hline & 2 & $\mathrm{C}_{25} \mathrm{H}_{20} \mathrm{NO}_{3}$ & 382.14 & 382.14 & $2,628,444$ & 0.07 \\
\hline & 3 & $\mathrm{C}_{29} \mathrm{H}_{20} \mathrm{~N}$ & 382.16 & 382.16 & $38,897,511$ & 0.23 \\
\hline & 4 & $\mathrm{C}_{26} \mathrm{H}_{24} \mathrm{NO}_{2}$ & 382.18 & 382.18 & $9,322,359$ & 0.36 \\
\hline & 5 & $\mathrm{C}_{27} \mathrm{H}_{28} \mathrm{NO}$ & 382.22 & 382.22 & $21,886,866$ & 0.32 \\
\hline & 6 & $\mathrm{C}_{28} \mathrm{H}_{32} \mathrm{~N}$ & 382.25 & 382.25 & $59,336,621$ & 0.31 \\
\hline & 7 & $\mathrm{C}_{25} \mathrm{H}_{36} \mathrm{NO}_{2}$ & 382.28 & 382.28 & $5,318,589$ & 0.23 \\
\hline & 8 & $\mathrm{C}_{26} \mathrm{H}_{40} \mathrm{NO}$ & 382.31 & 382.31 & $4,040,664$ & 0.66 \\
\hline
\end{tabular}


Dalong Formation has the highest abundance of $\mathrm{O}_{2}$ compounds with the detected $\mathrm{N}_{1} \mathrm{O}_{1} \mathrm{~S}_{1}$ compounds which contain sulfur. The Lucaogou Formation has the highest abundance of $\mathrm{N}_{1}$ compounds without $\mathrm{S}$ compounds, which indicates the marine shale has sulfur. Barrow et al. (2003), Stanford et al. (2007), Bae et al. (2010), and Li et al. (2013) studied oils and shale oils from different geological sources, and found that the composition and distribution of the NSO compounds varies from different source rocks and source oils. The following discussion is mainly based on two compound types $\left(\mathrm{O}_{2}\right.$ compounds and $\mathrm{N}_{1}$ compounds), because the samples are rich in $\mathrm{O}_{2}$ compounds or $\mathrm{N}_{1}$ compounds (Fig. 4).

In negative-ion ESI, the neutral nitrogen compounds and the acids are ionized selectively, so the $\mathrm{N}_{1}$ compounds and $\mathrm{O}_{2}$ compounds are neutral nitrogen compounds and acidic compounds. The $\mathrm{N}_{1}$ compounds contain pyrrole rings (Liu et al. 2014). The Dalong Formation has $11.7 \%$ of $\mathrm{N}_{1}$ compounds and $45.6 \%$ of $\mathrm{O}_{2}$ compounds; while the Lucaogou Formation has $49.3 \%$ of $\mathrm{N}_{1}$ compounds and $21.4 \%$ of $\mathrm{O}_{2}$ compounds. The geological nitrogen compounds are composed of amino acids, which originate from the sedimentary organic material reformed by diagenesis (Baxby et al. 1994). The main compositions of plankton and bacteria in the organic matter are protein (over 50\%), while higher plants mainly contain lignin and cellulose with a content of protein of only 3\%-10\% (Zhu et al. 1997). Previous studies hold the view that the sedimentary environment has a predominant effect on the content of pyrroles, especially the neutral nitrogen compounds. They concluded that there are more pyrroles (nitrogen compounds) in salt lake and marine facies than in fresh water lacustrine environments (Zhu et al. 1997; Li et al. 1999). However, the results of this study differ from previous research. The source of organic material has an influence on the content of $\mathrm{N}_{1}$ compounds. The sedimentary environment of the Dalong Formation is a platform

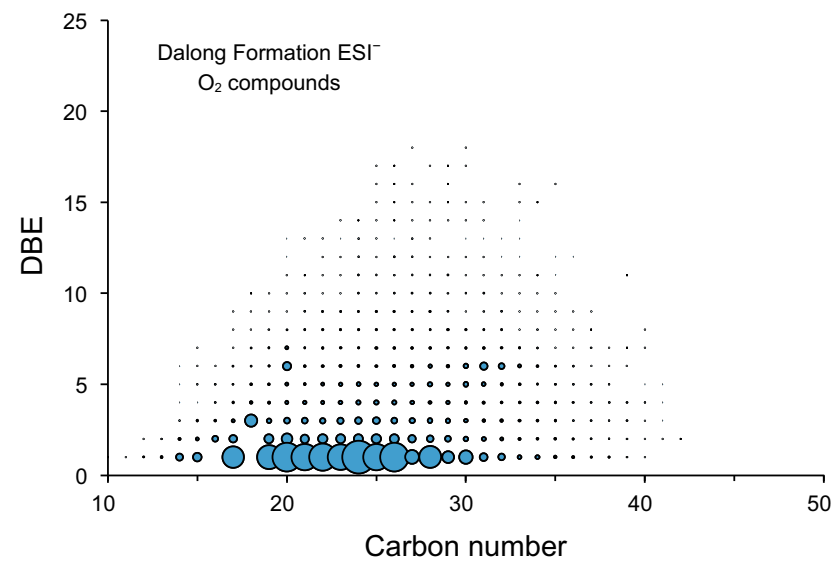

environment, which contained silicon and phosphorus. There are many benthic macroalgae, nematothallus, and acritarchs (Liang et al. 2009) in this environment. The type of organic material in the Dalong Formation is $\mathrm{II}_{1}$, which contains less protein. The sedimentary environment of the Lucaogou Formation is a deep or semi-deep lacustrine reducing environment, which cause that the type of organic material is I. Thus, the source material of the Lucaogou formation is lower aquatic organisms and phytoplankton, which contain lots of protein in the lacustrine reducing environment (Shen et al. 2015). Other studies concluded that the metabolisms of the micro-organisms need a lot of nitrogen compounds and that they can utilize inorganic nitrogen (Xiao et al. 2005). So the Lucaogou Formation is rich in pyrrolic nitrogen compounds, while the Dalong Formation is lacking them.

\subsection{The causes of the differences}

$\mathrm{O}_{2}$ compounds with $\mathrm{DBE}=1$ are fatty acids, while $\mathrm{O}_{2}$ compounds with $\mathrm{DBE}=2-4$ are naphthenic acids to tricyclic naphthenic acids. The main $\mathrm{O}_{2}$ compounds of the Dalong Formation are fatty acids $(\mathrm{DBE}=1)$ with an even number carbon preference, however, the naphthenic acids (DBE $=2,3,4)$ have lower contents. As for the Lucaogou Formation, the main $\mathrm{O}_{2}$ compounds are naphthenic acids $(\mathrm{DBE}=2)$, which also have an even number carbon preference; the fatty acids $(\mathrm{DBE}=1)$ and bicyclic naphthenic acids $(\mathrm{DBE}=3)$ have slightly lower contents than the naphthenic acids (Fig. 5). The fatty acids are one of the most abundant lipid markers, which are widely generated from marine phytoplankton (marine microalgae and macrophytes), zooplankton, terrestrial higher plants, and bacteria. However, the main source of fatty acids is marine microalgae. This is the reason that fatty acids in the Dalong Formation have the highest content of the $\mathrm{O}_{2}$ compounds and the lowest content of naphthenic acids. The higher

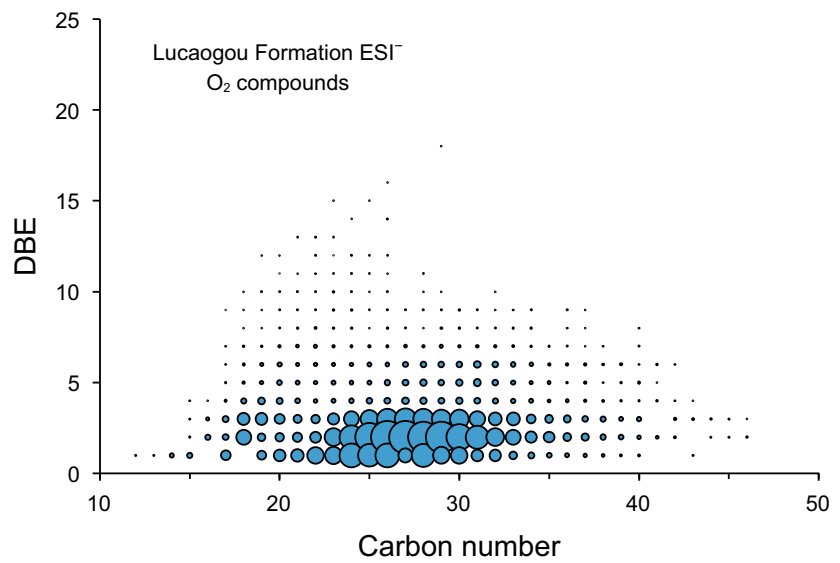

Fig. 5 Distribution of $\mathrm{O}_{2}$ compounds in DBE and carbon number of the two asphalts from different sources 

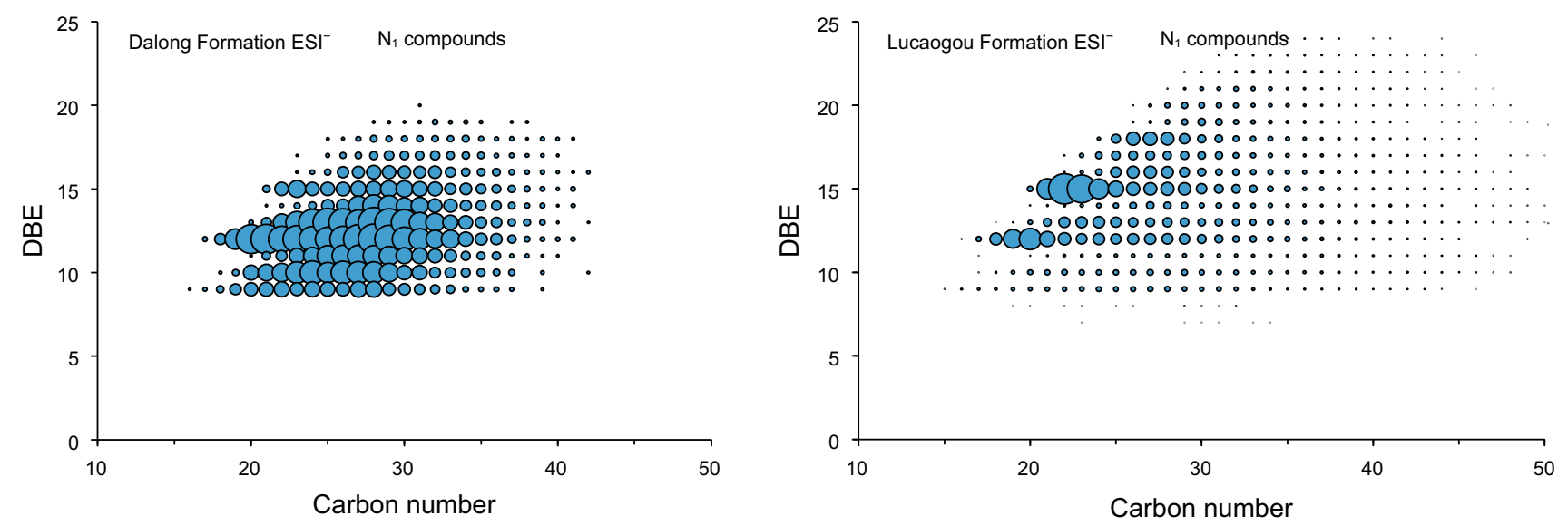

Fig. 6 Distribution of $\mathrm{N}_{1}$ compounds in DBE and carbon number of the two asphalts from different sources

content of naphthenic acids in the Lucaogou Formation is caused by slight biodegradation (Dou et al. 2007; Jing et al. 2014).

$\mathrm{N}_{1}$ compounds with $\mathrm{DBE}=9$ are carbazole compounds, while $\mathrm{N}_{1}$ compounds with $\mathrm{DBE}=12$ are benzocarbazole compounds. As for, $\mathrm{N}_{1}$ compounds with $\mathrm{DBE}=15$ are dibenzocarbazole compounds, $\mathrm{N}_{1}$ compounds with the $\mathrm{DBE}=10$ and 13 are the benzocarbazole compounds and dibenzocarbazole compounds which have a naphthenic ring. The $\mathrm{N}_{1}$ compounds in the Dalong Formation are rich in benzocarbazole compounds $(\mathrm{DBE}=12)$, with naphthenic carbazole $(\mathrm{DBE}=13)$. The carbazole $(\mathrm{DBE}=9)$, alkylcarbazole $(\mathrm{DBE}=10)$, and dibenzocarbazole $(\mathrm{DBE}=15)$ compounds have similar contents. The Lucaogou Formation has the highest contents of benzocarbazole and dibenzocarbazole, while other $\mathrm{N}_{1}$ compounds have lower contents (Fig. 6). Sumei Li holds the view that there may be few carbazole compounds in the marine sedimentary environment that cause the different distribution of DBE in the Dalong Formation and the Lucaogou Formation.

\section{Conclusions}

1. Based on the negative ESI FT-ICR MS technology, this research analyzed the distribution of the NSO compounds in two different sedimentary environments, and found that the asphalts from the Dalong Formation are composed mostly of carboxylic acids $\left(\mathrm{O}_{2}\right.$ compounds), especially fatty acids. The Lucaogou Formation asphalt is composed mostly of pyrrolic compounds, especially carbazole compounds $\left(\mathrm{N}_{1}\right.$ compounds).

2. The sedimentary environment of the Dalong Formation is a platform environment, which contains silicon and phosphorus. The main source material may be benthic macroalgae, nematothallus, and acritarchs, which contain less protein. The sedimentary environment of the Lucaogou Formation is a deep or semi-deep lacustrine reducing environment, in which the salinity of the water is quite high. The source material may be lower aquatic organisms and phytoplankton which contain abundant protein.

3. The technology of Fourier transform ion cyclotron resonance mass spectrometry works well for analyzing information about the sedimentary environment and the source material. In addition, this technology cannot only be used for the analysis of oils and oil fractions, but also for the analysis of source rocks and the extracts of source rocks.

Acknowledgements This work was supported by the National Natural Science Foundation of China (Grant No. 41672117), Shandong Provincial Key Laboratory of Depositional Mineralization and Sedimentary Minerals (Project No. DMSM201413) and Hubei Provincial Natural Science Foundation of China (Project No. 2017CFA027). We thank Professor Shi Quan for his help of experimental instruction and suggestion. And we are grateful to Zhang Yahe for the comments and scientific and linguistic revisions of the manuscript.

Open Access This article is distributed under the terms of the Creative Commons Attribution 4.0 International License (http://creative commons.org/licenses/by/4.0/), which permits unrestricted use, distribution, and reproduction in any medium, provided you give appropriate credit to the original author(s) and the source, provide a link to the Creative Commons license, and indicate if changes were made.

\section{References}

Bae EJ, Na JG, Chung SH, et al. Identification of about 30000 chemical components in shale oils by electrospray ionization (ESI) and atmospheric pressure photoionization (APPI) coupled with 15T Fourier transform ion cyclotron resonance mass spectrometry (FT-ICR MS) and a comparison to conventional 
oil. Energy Fuels. 2010;24(4):2563-9. https://doi.org/10.1021/ ef100060b.

Bao JP. A series of 25-norhopanes in oils and source rocks with no degradation. Chin Sci Bull. 1996;41(20):1875-8 (in Chinese).

Barrow MP, McDonnell LA, Feng XD, et al. Determination of the nature of naphthenic acids present in crude oils using Nanospray Fourier transform ion cyclotron resonance mass spectrometry: the continued battle against corrosion. Anal Chem. 2003;75(4):860-6. https://doi.org/10.1021/ac020388b.

Baxby M, Patience RL, Bartle KD. The origin and diagenesis of sedimentary organic nitrogen. J Pet Geol. 1994;17(2):211-30.

Dou LR, Hou DJ, Cheng DS, et al. Origin and distribution of highacidity oils. Acta Pet Sin. 2007;28(1):8-13. https://doi.org/10. 7623/syxb200701002 (in Chinese).

Fu XD, Qin JZ, Teng GE, et al. Evaluation on Dalong Formation source rock in the north Sichuan Basin. Pet Geol Exp. 2010;32(6):566-77 (in Chinese).

Hughey CA, Rodgers RP, Marshall AG, et al. Acidic and neutral polar NSO compounds in Smackover oils of different thermal maturity revealed by electrospray high field Fourier transform ion cyclotron resonance mass spectrometry. Org Geochem. 2004;35(7):863-80. https://doi.org/10.1016/j.orggeochem.2004.02.008.

Hughey CA, Galasso SA, Zumberge JE. Detailed compositional comparison of acidic NSO compounds in biodegraded reservoir and surface crude oils by negative ion electrospray Fourier transform ion cyclotron resonance mass spectrometry. Fuel. 2007;85(5-6):758-68. https://doi.org/10.1016/j.fuel.2006.08.029.

Jing W, Zhu R, Hu J. Identification and geochemical significance of polarized macromolecular compounds in lacustrine and marine oils. Chin J Geochem. 2014;33(4):431-8. https://doi.org/10. 1007/s11631-014-0709-8.

Kendrick E. A mass scale based on $\mathrm{CH}_{2}=14.0000$ for high resolution mass spectrometry of organic compounds. Anal Chem. 1963;35(13):2146-54. https://doi.org/10.1021/ac60206a048.

Kim S, Stanford LA, Rodgers RP, et al. Microbial alteration of the acidic and neutral polar NSO compounds revealed by Fourier transform ion cyclotron resonance mass spectrometry. Org Geochem. 2005;36(8):1117-34. https://doi.org/10.1016/j.orggeo chem.2005.03.010.

Liang DG, Guo TL, Bian LZ, et al. Some progresses on studies of hydrocarbon generation and accumulation in marine sedimentary regions, Southern China (part 3): controlling factors on the sedimentary facies and development of Palaeozoic marine source rocks. Mar Orig Pet Geol. 2009;14(02):1-19. https:// doi.org/10.3969/j.issn.1672-9854.2009.02.001 (in Chinese).

Li SM, Wang TG, Zhang AY, et al. Geochemistry characteristics and significance of the pyrrolic compounds in petroleum. Acta Sedimentol Sin. 1999;17(02):312-7. https://doi.org/10.3969/j. issn.1000-0550.1999.02.025 (in Chinese).

Li SM, Pang XQ, Jin ZJ, et al. Characteristics of NSO's compounds in sediment and their geochemical significance. Geochimica. 2001;30(4):347-52. https://doi.org/10.3321/j.issn:0379-1726. 2001.04 .007 (in Chinese).

Li SM, Meng XB, Zhang XB, et al. Geochemical significance of FTICR MS and its application in petroleum exploration. Geoscience. 2013;27(01):124-32. https://doi.org/10.3969/j.issn. 1000-8527.2013.01.013 (in Chinese).

Liu P, Xu C, Shi Q, Pan N, et al. Characterization of sulfide compounds in petroleum: selective oxidation followed by positive-ion electrospray Fourier transform ion cyclotron resonance mass spectrometry. Anal Chem. 2010;82(15):6601-6. https://doi.org/10.1021/ac1010553.

Liu P, Li MW, Sun YG, et al. Characterization of polar species in rock extracts by ultrahigh resolution mass spectrometry. J Instrum Anal. 2014;33(1):57-62. https://doi.org/10.3969/j.issn. 1004-4957.2014.01.010 (in Chinese).
Lu H, Shi Q, Lu J, et al. Petroleum sulfur biomarkers analyzed by comprehensive two-dimensional gas chromatography sulfurspecific detection and mass spectrometry. Energy Fuels. 2013;27(12):7245-51. https://doi.org/10.1021/ef401239u.

Luo Q, George SC, Xu Y, et al. Organic geochemical characteristics of the Mesoproterozoic Hongshuizhuang Formation from northern China: implications for thermal maturity and biological sources. Org Geochem. 2016;99:23-37. https://doi.org/10.1016/ j.orggeochem.2016.05.004.

Luo Q, Qu Y, Chen Q, et al. Organic geochemistry and petrology of Mudrocks from the upper carboniferous Batamayineishan Formation, Wulungu Area, Junggar Basin, China: implications for petroleum exploration. Energy Fuels. 2017;31(10):10628-38. https://doi.org/10.1021/acs.energyfuels.7b01754.

Peng XF, Wang LJ, Jiang LP. Analysis of sedimentary environment of the Permian Lucaogou Formation in Southeastern Margin of the Junggar Basin. J Xinjiang Univ (Nat Sci Ed). 2011;28(4):395-400. https://doi.org/10.3969/j.issn.1000-2839. 2011.04.004.

Qian K, Robbins WK, Hughey CA, et al. Resolution and identification of elemental compositions for more than 3000 crude acids in heavy petroleum by negative-ion microelectrospray high-field Fourier transform ion cyclotron resonance mass spectrometry. Energy Fuels. 2001;15(6):1505-11. https://doi.org/10.1021/ ef010111z

Shen HL, Wang J, Yu Q, et al. The Junggar Basin, Source of Midong Lucaogou Formation rock geochemical characteristics of kerogen. Sichuan Build Mater. 2015;41(2):234-7. https://doi.org/10. 3969/j.issn.1672-4011.2015.02.112 (in Chinese).

Shi Q, Zhao S, Xu Z, et al. Distribution of acids and neutral nitrogen compounds in a Chinese crude oil and its fractions: characterized by negative-ion electrospray ionization Fourier transform ion cyclotron resonance mass spectrometry. Energy Fuels. 2010;24(7):4005-11. https://doi.org/10.1021/ef1004557.

Shi Q, Pan N, Long H, Cui D, et al. Characterization of middletemperature gasification coal Tar. Part 3: molecular composition of acidic compounds. Energy Fuels. 2013;27(1):108-17. https:// doi.org/10.1021/ef301431y.

Stanford LA, Rodgers RP, Marshall AG, et al. Detailed elemental compositions of emulsion interfacial material versus parent oil for nine geographically distinct light, medium, and heavy crude oils, detected by negative- and positive-ion electrospray ionization Fourier transform ion cyclotron resonance mass spectrometry. Energy Fuels. 2007;21(2):973-81. https://doi.org/10.1021/ ef060292a.

Wang PR. Application of non-hydrocarbon geochemistry. Beijing: Petroleum Industry Press; 2002. p. 15-30 (in Chinese).

Wang PR, Zhao H, Zhu CS, et al. General review of non-hydrocarbon geochemistry and its application. Acta Sedimentol Sin. 2004;30(1):98-105. https://doi.org/10.3969/j.issn.1000-0550. 2004.z1.016 (in Chinese).

Xia ML, Weng L, Wang YG, et al. High-quality source rocks in trough facies of upper Permian Dalong Formation of Sichuan Basin. Pet Explor Dev. 2010;37(6):654-62 (in Chinese).

Xiao QL, He S, Li YF, et al. Review of distribution and origin of organic nitrogen compounds in sediments. Geol Sci Technol Inf. 2005;24(3):60-6. https://doi.org/10.3969/j.issn.1000-7849.2005. 03.012 (in Chinese).

Zhao XF, Zhao YS, Deng QY, et al. Preliminary study of the sequence stratigraphy of upper Permian Lucaogou and Hongyanchi formation on the southern edge of Jungar Basin. J Chengdu Inst Technol. 1994;21(3):112-20 (in Chinese).

Zhu YM, Fu JM, Sheng GY, et al. The geochemical significance of pyrrole compounds with different origins in Tarim Basin. Chin Sci Bull. 1997;42(23):2528-30. https://doi.org/10.3321/j.issn: 0023-074x.1997.23.015 (in Chinese). 